\title{
Toxic Air and Soil in Automobile Workshop Impact Negatively on the Health Status of Automechanics: The Nigeria Environment
}

\author{
Atuboyenia W. Obianime ${ }^{1}$, Obianuju Odili ${ }^{2}$, Oluwadare J. Olorunfemi ${ }^{2}$ \\ Tekena O. Wokoma ${ }^{2}$ and Arthur N. Chuemere ${ }^{2}$
}

\begin{abstract}
${ }^{1}$ Department of Pharmacology, Faculty of Basic Medical Sciences, College of Health Sciences, University of Port Harcourt, P.M.B 5323 Choba, Port Harcourt, Nigeria.

${ }^{2}$ Department of Human Physiology, Faculty of Basic Medical Sciences, College of Health Sciences, University of Port Harcourt, P.M.B 5323 Choba, Port Harcourt, Nigeria.
\end{abstract}

*Corresponding author: Arthur N. Chuemere, Department of Human Physiology, Faculty of Basic Medical Sciences, College of Health Sciences, University of Port Harcourt, P.M.B 5323 Choba, Port Harcourt, Nigeria, E-mail: arthur.nwafor@uniport.edu.ng

Received: February 28, 2017; Revised: July 10, 2017; Published: August 10, 2017

Copyright: (02017 Obianime AW, et al. This is an open-access article distributed under the terms of the Creative Commons Attribution License, which permits unrestricted use, distribution, and reproduction in any medium, provided the original author and source are credited. The article has been previewed and authenticated by the Authors before sending the publication for print. The Journal, Editor and the Editorial Board are not entitled or liable to either justify or responsible for inaccurate and misleading data if any. It is the sole responsibility of the Author concerned.

Citation: Obianime AW, Odili O, Olorunfemi OJ, et al. Toxic Air and Soil in Automobile Workshop Impact Negatively on the Health Status of Automechanics: The Nigeria Environment. Int J Pharm Pharmacol 2017; 1: 111. doi: 10.31531/2581-3080.1000111

\footnotetext{
Abstract

Objective: Auto-mechanics are constantly in contact with both air and soil harmful chemicals and toxic substances in their environment. A comparative cross-sectional study of analysis of hazardous stationary emissions of air and soil petroleum pollutants in automobile workshops has been analyzed. Furthermore, the impact of prolonged or continual occupational and environmental exposure on health of auto-mechanics from two distinct and contrasting automobile workshop environments was studied.

Methods: Data were collected by a questionnaire interview designed about occupational activities, lung functions and blood samples of the subjects, soil samples and air qualities from automobile workshops and control sites were collected for analysis. Samples were collected from June to September 2016, during the rainy season.

Results: Auto-mechanics are at higher risk for respiratory, hepatic, reproductive, haematological, immune, platelet and selenium dysfunctions, as a result of direct exposure to both volatile organic compound $(0.212 \mathrm{ppm})$ and total petroleum hydrocarbon $(62.370 \mathrm{mg} / \mathrm{kg})$ toxicities, respectively. There were substantial regional variations in the burden of the petroleum toxicant estimates, with Ihiala bearing most of the burdens compared with Port Harcourt and Obrikom. The present data revealed increase in concentration of some liver enzymes, total bilirubin, total protein, mean platelet volume, but decrease in selenium, red blood count, white cell count, haemoglobin, haematocrit, testosterone, force expiratory volume in auto-mechanics in comparison with control $(p \leq 0.05)$.
} 


\section{Introduction}

Environmental pollution generally is defined as the contamination of soil, water or the atmosphere by the discharge of substances that are harmful to living things. Petroleum-related activities worldwide and Nigeria in particular, have raised concerns about the adverse effects of contamination of petroleum products on the environment. Hitherto, human exposure has been associated with growing incidence of a range of acute and long-term adverse health effects and diseases [1-8]. Indeed, it has been estimated that, globally, upwards of $24 \%$ of human diseases and disorders are attributable to environmental factors [9] and that the environment plays a role in $80 \%$ of the most deadly diseases, including cancer, respiratory and cardiovascular diseases [10]. Notwithstanding, human health symptoms / signs associated with living or working in an area exposed to such pollutants have not been elucidated clearly with respect to professional contacts and emission sources. Nevertheless, the actual mechanisms by which these environmental pollutants of oil fire and waste gas flaring directly or indirectly alter regulatory pathways are elusive.

Professional auto-mechanics in Nigeria are at high risk to discharges of toxic or contaminating crude oil and its refined products that are likely to have an adverse effect on the environment or life. Unfortunately, there are little or no information about automotive workshop inspection checklists, automotive environmental regulations and automotive workshop environmental policy in Nigeria.

Nonetheless, literature of environmental concentrates of stationary emissions of both soil and air pollutants, specifically petroleum product and effects on human bodily functions is lacking. Studies have established association of the automobile workshop with adverse health effects on automobile workers [4,11] while some has suggested contrarily [12]. Evidence exist which suggests that automechanic workshop soils are potential source of pollution to the environment as well as to life [13-17], selectively supports the growth of petroleum hydrocarbon microorganism utilizers [18]. Furthermore, it has been recognized that activities in auto-mechanical workshops increase air pollution [19-20] which has short and long-term effects on lung health [21]. Worldwide, approximately 3.7 million and 4.3 million premature deaths are attributed to ambient (outdoor) air pollution and household (indoor) air pollution in 2012, respectively. Importantly, air pollution has risen by $8 \%$ globally in the past five years, causing approximately 3 million premature deaths a year, making it one of the greatest environmental risks to human health [22]. This research was designed to analyze and compare environmental associated toxic levels of both soil and air pollutants in two distinct and contrasting automobile workshop environments and the impact on automobile mechanics to establish the possible effect they have on human beings and environment which has been rare.

\section{Materials and Methods}

\section{Description of Subject and Location}

This study was carried out using asymptomatic male subjects for 4 months from June to September 2016, during the rainy season. One hundred and twenty auto-mechanics: 56 (26.4\%), $28(13.2 \%)$ and $36(17 \%)$ from Port Harcourt, Obrikom and Ihiala respectively that had been subjected to long term and continuous exposures to environmental pollution in the automobile workshops were recruited for the study. Ninety-two non-auto-mechanics: 40 (18.9\%), 20 (9.4\%) and $32(15.1 \%)$ from Port Harcourt, Obrikom and Ihiala respectively were selected as control, that is, they have no contact with petroleum toxicants. The controls for the study were panel beaters, spare part dealers and voluntary individuals who had non-chemical related occupations.

A special questionnaire was designed about occupational activities, age of subjects, 
socioeconomic status, clinical characteristics, duration of stay at work place and age of establishment of the workshop was completed by each participant. On the average, the age range of the participants was 35 to 70 years with mean age $(\mathrm{SEM}) 43 \pm 3.4$. The automechanics had been exposed to environmental pollution contaminants of soil and air for about eight hours a day per week and in the order of ten years and above. Three sampling locations were established. Two sampling stations were within Rivers State one in Port Harcourt and the other in Obrikom, both are in the Niger Delta region, and the third sampling station Ihiala in Anambra State.

Study area 1 Port Harcourt: Port Harcourt is a cosmopolitan town, the capital city of Rivers State. It is economically significant as the centre of Nigeria's oil and gas industry.

Study area 2 Obrikom: Obrikom is a notable oil fires and waste gas flaring zone in Rivers State, and is approximately $78 \mathrm{~km} / 49$ miles away from Port Harcourt the capital of Rivers State and approximately $416 \mathrm{~km} / 258$ miles, from Abuja, the capital of Nigeria. Obrikom is in Ogba / Egbema district in Ogba Egbema Ndoni L.G.A, Rivers State, Nigeria and on latitude (width) $5^{\circ} 23^{\prime} 41.4^{\prime \prime} \mathrm{N}\left(5.3948200^{\circ}\right)$ and Longitude (length) $6^{\circ} 40^{\prime} 06.7 " \mathrm{E}\left(6.6685300^{\circ}\right)$ $[6,23]$. The delta covers approximately $20,000 \mathrm{~km}^{2}$ within wetlands, this floodplain makes up $7.5 \%$ of Nigeria's total land mass. The delta region is the largest wetland and maintains the third-largest drainage basin in Africa [24].

Study area 3 Ihiala: Ihiala is a city located in the south of Anambra State in southeastern Nigeria, and has long served as the local administrative capital of the zone [25]. Ihiala is also a Local Government Area. It has no oil fires and waste gas flaring exploration and exploitation activities. Ihiala is about $367 \mathrm{~km} /$ 228-mile South of Abuja, the country's capital town and about $33 \mathrm{~km} / 21$ miles from Onitsha, a densely populated commercial / manufacturing city in the industrial hub of eastern Nigeria. Ihiala-Onitsha axis according to WHO report, is in number one place as the most polluted out of the 3,000 cities in the WHO's air quality database, which recorded roughly 30 times more than the WHO's Obianime AW, et al. Int J Pharm Pharmacol recommended levels of particulate concentration (PM10) [26].

\section{Ethical Considerations}

Blood samples were collected from the participants after written informed consent. The study protocol was approved by the ethical committee on human biomedical research of the University. Rules and guidelines governing sample collection from humans for research purposes were strictly followed.

\section{Air Quality Analysis}

Air samples from the workplaces indoor/outdoor/under the shades were trapped using an industrial scientific corporation IBRID MX6 Multi-Rae Gas monitor to measure the presence of Methane $\left(\mathrm{CH}_{4}\right)$ and Volatile Organic Compounds (VOCs) by following the procedure given by the manufacturer.

\section{Soil Analysis}

Surface soil from the three locations including the control sites for assessing petroleum hydrocarbon contamination were collected in close proximity at a depth of $0-15 \mathrm{~cm}$ using calibrated auger. The age of establishment of auto-mechanical workshops was in the order of excess of 10 years. It has been previously reported that the age of auto-mechanical workshops [17,18,27] depth of the soil [28] duration and concentration of exposure [29] are important in the determination of soil pollution. Total petroleum hydrocarbon (TPH) [29] was measured with soil samples taken indoor/outdoor/under the shades using Gas Chromatography-Flame Ionization Detector (USEPA 8440) as described by the manufacturer.

\section{Lung Function Analysis}

Force expiratory volume (FEV) of the subjects was measured by the use of a Windmill-Type Spirometer. Subjects while seated inhaled deeply and stretched upward. After maximum inhalation with the mouthpiece of the instrument held between the lips, breathed out strongly in one motion, making sure that all air was forced into the mouth piece. The test was repeated thrice for each subject and the average value was taken. 


\section{Blood Sample Collection and Blood Count Analysis}

Blood samples of $10 \mathrm{ml}$ was collected from the arm of each subject and stored in sterile potassium EDTA and lithium free heparinized anticoagulant bottles. The blood sample was used for the valuation of the liver, haematological, blood metal, hormonal and biochemical effects of petroleum poisoning in exposed individuals and controls. Haematological and platelet indices were analyzed in whole blood using an autohaematology analyzer by following the procedure given in the kit protocol.

\section{Male Reproductive Endocrine status}

Serum hormonal assay was carried out using testosterone enzyme immunoassay test kit, catalog number: BC-1115, Bio Check, Inc 837 Cowan Road, Burlingame, CA94010.

\section{Biochemical Markers of Liver Function Analysis}

Quantitative in-vitro determination of biochemical assays was done on auto biochemical analyzer-Rx Monza analyzer, Cat No. AB 362 by following the procedure given in the kit protocol.

\section{Blood Metal Analysis}

Metals in blood were analyzed using Atomic Absorption Spectrophotometer as described by the manufacturer.

\section{Statistical Analysis}

Data were evaluated for significant differences between control and experimental groups and were assessed and determined using SPSS for window XP software programme (version 18.) for independent T-test and one-way ANOVA followed by Scheffe, Tukey, Duncan and LSD post hoc multiple comparisons. The data were expressed as mean \pm SEM at $\mathrm{p} \leq 0.05$. Data were considered significant at $\mathrm{p} \leq 0.05$.

\section{Study Limitations}

The study was limited in that few subjects participated in the study and limiting to little experimentation which limits to generalization of results to the total auto-mechanics workshops. Most importantly, the study was carried out during the rainy season. This could be improved upon in the future by performing variety of tasks in several different workshops and under varying weather conditions. Time and availability of fund was also a limiting factor for the performance of the research. Furthermore, there were no records for baseline and periodic medical examination of workers to identify changes that could be attributed to contamination of petroleum pollutants.

\section{Results}

Figure 1 depicts the harmonic mean toxicity levels of volatile organic compounds (air pollutants) and total petroleum hydrocarbons (soil pollutants) recorded in auto-mechanic workshops compared with control. Volatile organic compounds showed substantial regional variations increasing gradually from the wetland (Port Harcourt and Obrikom, 0.16 $\mathrm{ppm}$ ) to hinterland (Ihiala, $0.60 \mathrm{ppm}$ ) compared to control values of $0.7 \mathrm{ppm}$ and $0.5 \mathrm{pmm}$ respectively (Figure 1). Overall, harmonic mean toxicity values of volatile organic compounds (VOC, $0.212 \mathrm{ppm}$ ) was statistically significantly lower $(\mathrm{p} \leq 0.05)$ compared to control sites $(0.618 \mathrm{ppm})$. Traces of methane $(0.1 \mathrm{ppm})$ together with volatile organic compounds were also recorded in the automobile workshops and the control sites respectively.

Total petroleum hydrocarbon levels in the workshop at delta region (TPH, $54.794 \mathrm{mg} / \mathrm{kg}$ ) were significantly lower in comparison to hinterland-Ihiala $(86.207 \mathrm{mg} / \mathrm{kg})$. However, the reverse was the case for the control values of $814 \mathrm{mg} / \mathrm{kg}$ and $35.65 \mathrm{mg} / \mathrm{kg}$ respectively (Figure 1). Overall, the harmonic mean toxicity values of total petroleum hydrocarbons in the workshop $(62.370 \mathrm{mg} / \mathrm{kg})$ was statistically significantly higher $(\mathrm{p} \leq 0.05)$ in comparison to control sites $(98.34 \mathrm{mg} / \mathrm{kg}$ ) (Figure 1). Generally, there was also differential accumulation of the petroleum toxicant estimates between the control sites

Table 1 shows the mean values of biochemical markers of liver functions. Data revealed that liver enzyme alkaline phosphatase, total bilirubin and total protein increased with 
corresponding decrease in liver enzymes aspartate aminotransferase and alanine aminotransferase, conjugated bilirubin and albumin in comparison to control, and the difference was statistically significant $(\mathrm{p} \leq$ $0.05)$.

Table 2 shows the mean value of red blood profiles. Data indicated that red blood cell count, hemoglobin and hematocrit were reduced with corresponding statistically significant $(\mathrm{p} \leq 0.05)$ increased mean corpuscular volume, mean corpuscular hemoglobin, and mean corpuscular hemoglobin concentration values in comparison with control.

Mean values of white blood cell parameters are shown in Table 3. Data revealed that white blood cell parameters of the auto-mechanics were statistically significantly lower compared with control $(\mathrm{p} \leq 0.05)$.

Table 4 depicts mean value of platelet parameters for the cohorts. Data indicated that with exception of mean platelet volume (FL), other platelet parameters were statistically significantly lower $(\mathrm{p} \leq 0.05)$ compared with control.

Figure 2 compares mean force expiratory volume and testosterone level of automobile workers compared with non-mechanics (control). Data indicated that force expiratory volumes $(\mathrm{FEV}, \mathrm{L})$ for automobile workers were statistically significantly lower $(p \leq 0.05)$ in comparison to control. The mean values for force expiratory volume of automobile workers $(2.20 \mathrm{~L})$ was significantly lower $(\mathrm{p} \leq 0.05)$ compared with control $(3.35 \mathrm{~L})$.

Data further revealed that the mean testosterone level of auto-mechanics $(7.20 \pm 0.10)$ was statistically significantly lower $(\mathrm{p} \leq 0.05)$ compared with control $(9.55 \pm 0.45)$ (Figure 2) With the exception of selenium (ppm) that reduced significantly in auto-mechanics $(0.04 \pm$ $0.01)$ in comparison with referents $(0.31 \pm$ 0.28 ), the difference in chromium, copper, zinc, cadmium, vanadium was statistically nonsignificant $(\mathrm{P}<0.05)$. Mercury, nickel, and arsenic were not detected in the blood samples of both groups (Table 5).

Obianime AW, et al. Int J Pharm Pharmacol

\section{Discussion}

This study has demonstrated evidence of possible toxic level of hazardous stationary emissions predominantly accumulation of both volatile organic compounds and total petroleum hydrocarbons in automobile workshops and potential health impact. The automobile workshop obviously mimics typical Nigeria environment. It is an outrage that since the inception of the oil and gas exploration and exploitation more than fifty years ago in Nigeria, there has been no concerned and effective effort on the part of the government, let alone the oil and gas operators, to control environmental pollution and worst still, the associated health problems with the industry. Generally, tens of thousands and millions of Nigerians are being exposed to illegal levels of environmental pollutants from diverse sources that breach international legal limits and cause lifelong health problems. Perhaps this might be a contributory factor to a significantly higher risk for low life expectancy rates of Nigerian citizens [30]. Herein, our subjects were unaware of their health status. The results of the occupational and environmental exposure to petroleum toxicant effects on bodily functions that could have entered the body through skin, lungs, and intestinal tract contacts or sundry other exposure routes are described in Tables 15 and figures 1-2, respectively. Studies dealing with individual substances, volatile organic compounds (VOC) and total petroleum hydrocarbons (TPH) have been treated in literature as one class of substance. Specifically, major contaminants that are components of total petroleum hydrocarbons and volatile organic compounds are benzene, toluene, ethyl benzene, and xylene (BTEX). Many of the harmful effects seen after exposure have been attributed to these individual chemicals. The mechanisms underlying these effects are poorly understood. Although several hypotheses have been postulated, organ systems that can be affected by their prolonged exposure include the pulmonary, neurologic, cardiac, gastrointestinal, hepatic, renal, dermatologic, haematologic; alterations of lipids metabolisms and some biochemical activities [3,29,31-32].

The present study of occupational and environmental exposure effect on health risks, 
to the best of our knowledge, is the first study to evaluate petroleum toxicants of air and soil origins, respectively in automobile workshops. However, the toxicants did not show regional variations in the burden of health risks, but in pollutant estimates. The harmonic mean toxicity values of volatile organic compounds $(0.60 \mathrm{ppm})$ and total petroleum hydrocarbons $(86.207 \mathrm{mg} / \mathrm{kg})$ were much higher at Ihiala in comparison with Port Harcourt/Obrikom of $0.260 \mathrm{ppm}$ and $54.794 \mathrm{mg} / \mathrm{kg}$ respectively. This showed the possibility of regional differences order than seasonal changes [33-34] in accumulation of petroleum toxicants in the environment. The preponderance of the pollutants at Ihiala collaborates with WHO's report of high levels of environmental pollution in Ihiala-Onitsha axis of Nigeria that have roughly 30 times more than the WHO's recommended levels of particulate matter (PM10) particles, and is in number one place as the most polluted city in the world [26].

The study revealed though the levels of the liver enzymes and proteins were within the reference range for healthy individuals, the values for the auto-mechanics were significantly different to non-auto-mechanics collaborating with similarly researchers $[11,38$ 40] but differs from other studies [12,41]. In consideration of the indicators of hepatotoxicity which could be part of the potential health risks following exposure to petroleum contaminants, the result revealed significant difference in serum bilirubin (total bilirubin and conjugated bilirubin), serum proteins (albumin and total protein) and liver enzymes (alanine aminotransferase, aspartate aminotransferase and alkaline phosphatase) activities between occupationally exposed in comparison with referents. Variation in the markers observed between both groups showed significant increase $(\mathrm{P}<0.05)$ in enzyme activities of alkaline phosphatase, total bilirubin levels and total protein, an indication that the exposed groups are predisposed to alteration in transport function of hepatocytes and/or developing haemolytic anaemia. It is possible that the hydrocarbon pollutants may interfere with the enzymatic activities of glucuronltransferase by inhibiting bilirubin conjugation thereby becoming water-insoluble. Consequently, bilirubin may not be excreted from the bile into duodenum and removed from the body. The result of the findings definitely rules out infective conditions such as viral hepatitis as aspartate aminotransferase and/or alanine transaminase ought to have increased correspondingly $[11,39]$. The observation of elevated bilirubin concentrations either as a result of increased production due to increase degradation of haemoglobin, conjugation, decreased secretion by the liver or blockage of the bile ducts in the exposed groups is in agreement with previous report [11].

Notably, the mean values of blood cell types in the present study were still within parametric reference range, differences were also found in the exposed groups in comparison to referents. In contrast to previous human studies [4,42] including animal models [43], the present study revealed that haemoglobin, red blood cell count and haematocrit values were reduced. Correspondingly, there was statistically significant increase mean corpuscular volume, mean corpuscular haemoglobin, and mean corpuscular haemoglobin concentration values in the exposed groups than the comparison, an indication of adverse red blood cell disorders. The observed decrease in haemoglobin level of auto-mechanics is in correlation with previous studies [11] but differs from the report on oil works where the values for haemoglobin and haematocrit remained insignificant difference $(\mathrm{P}>0.05)$ between both groups [8]. Our findings also collaborate with the assertion that the length of exposure to petroleum pollutants correlates with adverse effect on haematological physio-chemistry [4,8,44-45].

Looking at the white blood cell parameters, there was statistically significantly $(p<0.05)$ reduced levels of total leucocyte count, together with differential white blood cell counts lymphocyte, neutrophil, monocyte, eosinophil and basophil in the exposed groups in comparison with referents. This is an indication of possibility that auto-mechanics might be highly susceptible to malignant disorders of white blood cells and white blood cell precursors or immune system proteins. In contrast to studies among oil workers, both the white blood cell and platelet (see below) counts showed variable decreases or depressions but also remained insignificant $(\mathrm{P}>0.05)$ in exposed oil workers compared with referents [8]. In 
stimulated model study on the other hand, white blood cell count, neutrophil and eosinophil values were higher while that of the lymphocytes were reduced in petrol treated groups compared with control [43].

Platelet profile results in the present study though compared well with those of other studies [46-49]. However, platelet count and platetcrit values were present in significantly lower numbers in the exposed groups compared with control $(\mathrm{p}<0.05)$, suggesting that automechanics might be predisposed to developing severe illnesses and higher risks of death [50]. The observation of simultaneous reduction of platelet count and platetcrit levels may possibly be attributable to excessive destruction of platelets which might lead to slowing the production of platelets in the bone marrow, consequently contributing to inflammation, thrombosis, and cardiovascular physiopathology [49,51]. Further, platelet count and platetcrit reduction might inhibit platelet releasing proteins and small molecules from their granules, and negatively influence the functions of the vascular wall and circulating immune cells [51]. Together, these findings support various studies elsewhere which conclude that petroleum pollutants contain potentially haematotoxic substances capable of causing haematological disturbances, plausibly through their toxic effects on the haematopoietic stem cell mechanisms. Notably, the mean age of the subjects $(43 \pm 3.4)$ fall within the age range 40-49 years and above considered to be at higher health risks for blood cell type disturbances following exposure to petroleum toxicants [8].

Results of the present study also demonstrated statistically significantly low level of selenium in the exposed groups in comparison with control, manifestation that petroleum pollutants have adverse effect on the antioxidant bodily functions of selenium. The observation of low level of selenium, rather selenium deficiency, is suggestive that the exposed population might be more susceptible to the development of cardiovascular disease, cancer, diabetes, Inflammation and inflammatory disorders, infertility, hypothyroidism, weakened immune system, depressed mood and hostile behave or or cognitive decline [52-53].
The present study also showed that the hazardous air pollutants in the automobile workshop impacted negatively on the respiratory functions of the auto mechanics in comparison with control, an indication of pulmonary function impairment [54-55]. The decline in the respiratory functions is suggestive of vulnerability of auto-mechanics to stroke, heart disease, lung cancer, and chronic and acute respiratory diseases, including asthma [56].

The observation in this study of low level of testosterone compared to control groups ( $\mathrm{p} \leq$ $0.05)$, is consistent with the view that petroleum products contain endocrine disrupting chemicals capable of inducing male reproductive toxicities [33,57-58]. Stationary emission induced testosterone decrease possibly could be due to induction of oxidative stress and inhibition of steroidogenesis and negatively regulated the hypothalamus pituitary- gonad axis leading to reproductive problems [34,58]. Similarly, reduction in testosterone level has been reported in male reproductive health stimulated studies which also suggested that petroleum toxicants have adverse effect on reproductive health including testosterone dysfunctions [59-61].

\section{Conclusion}

Gas Chromatography-Flame Ionization Detector (USEPA 8440) and IBRID MX6 Multi- Rae Gas monitor has been used to provide first line evidence for the toxic levels of volatile organic compounds and total petroleum hydrocarbons respectively in automobile workshops that is permanently affecting life that have been largely undetermined. Together, this work further proposed the possible pathophysiological consequences- haematotoxicity, hepatotoxicity, respiratory impairment, reproductive, immuno-physiological and selenium disturbances and thrombocytopenia which perhaps may exert important influence on further disease manifestations with resultant death. The present findings, we hope would provide baseline data which could be used for further studies. 


\section{Conflict of Interests}

No conflicts of interest, financial or otherwise, are declared by the authors.

\section{References}

1. Joffa PKP, Nwafor A, Adienbo MO. Correlation between body mass index and peak expiratory flow rate of an indigenous Nigerian population in the Niger Delta Region. Res J Rec Sci 2013; 2: 28-32.

2. Egwurugwu JN, Nwafor A. Prolonged exposure to oil and gas flares ups the risks for hupertension. Am J Heal Res 2013; 1: 65-72.

3. Egwurugwu JN, Nwafor A, Ezekwe A. Impacts of prolonged exposure to gas flares on some blood indices in humans in the Niger Delta Region, Nigeria. Arch Appl Sci Res 2013; 5: 98-104.

4. Ajugwo AO, Adias TC, Aghatise K, et al. Reduced haematological indices in automechanics and fuel attendants in Elele Nigeria. Am J Med Boil Res 2014; 2: 1-4.

5. Chuemere AN, Olorunfemi OJ, Nwogu JU, et al. Correlation between Blood group, Hypertension, Obesity, Diabetes, and combination of Prehypertension and PreDiabetes in School Aged Children and Adolescents in Port Harcourt. Inter Org Sci Res J Dent Med Sci 2015;14: 83-89.

6. Nwafor A, Mmom FC, Onybuchi O, et al. Relationship between Blood pressure, Diabetes, Blood glucose and coexisting prehypertension and pre-diabetes among rural adults in Rivers State, Niger Delta Region, Nigeria. Brit $\mathrm{J}$ Med Med Res 2015;.9: 1-12.

7. Mmom FC, Chuemere AN. A study of incidence and prevalence of hypertension, diabetes and obesity with blood type in postmenopausal in Females in Port Harcourt. Saudi J Biomed Res 2016; 1: 2229.

8. Ezejiofor TIN. Haematological indicator of exposure to petroleum products in petroleum refining and distribution industry workers in Nigeria. J Clin Toxicol 2016; 6: 276.

9. Fingerhut M, Nelson DI, Driscoll T, et al. The contribution of occupational risks to the global burden of disease: summary and next steps. La Medicina del lavoro 2006; 97: 313-321.

10. World Health Organization. Preventing disease through healthy environments towards an estimate of the environmental burden of disease. Geneva: World Health Organization 2006.

11. Khan AA, Inam S, Idrees M, et al. Effect of automobile workshop on the health status of automechanics in N. W. F. P., Pakistan. Afri Jf Environ Sci Tech 2010; 4: 192-200.

12. Adejumo BI, Ajayi IO, Dimkpa U, et al. Assessment of liver function of selected automobile professionals in south-south region of Nigeria. Inter J Environ Poll Res 2016; 4:16-24.

13. Adelekan BA, Abegunde KD. Heavy metals contamination of soil and groundwater at automobile mechanic villages in Ibadan, Nigeria. Inter J Phy Sci 2011; 6: 1045-1058.

14. Odor R, Agbaji EB, Kagbu JA. Assessment of the trace metals pollution in automechanic workshop in some selected local government area of Benue State, Nigeria. Inter J Chem 2011; 3: 78-88.

15. Adewoyin OA, Hassan AT, Aladesida AA. The impacts of auto-mechanic workshops on soil and groundwater in Ibadan metropolis. Afri J Environ Sci Tech 2013; 7: 891-898.

16. Ololade IA. An assessment of heavy-metal contamination in soils within automechanic workshops using enrichment and contamination factors with geoaccumulation indexes. J Environ Prot 2014; 5: 970-982.

17. Demie G. Analyzing soil contamination status in garage and auto mechanical workshops of Shashemane City: implication for hazardous waste management. Environ sys Res 2015; 4: 15.

18. Orji MU, Okoli I, Nwaogo MC et al. Dynamics of microbial population in petroleum- impacted soils in automobile mechanic workshops in Awka, Nigeria. Inter J Res Inno Earth Sci 2015; 2: 122-126.

19. Ekong, FU, Michael GUS, Michael US. Assessing the effects of mechanic activities on Uyo air environment. Ethio J Environ Stud Man 2012; 5: 74-85.

20. Ahmad I, Rehan M, Balkhyou MA, et al. Review of environmental pollution and 
health risks at motor vehicle repair workshops: challenges and Perspectives for Saudi Arabia. Int J Agric Environ Res 2016; 2: 1-23.

21. Delzell JE Jr. Common lung conditions: environmental pollutants and lung disease. FP Essent 2013; 409: 32-42.

22. WHO Expert Meeting: Methods and tools for assessing the health risks of air pollution at local, national and international level Meeting report Bonn, Germany, 12-13 May 2014.

23. Agbalagba EO, Avwiri GO, Ononugbo CP. Activity concentration and radiological impact assessment of $226 \mathrm{Ra}, 228 \mathrm{RA}$ and $40 \mathrm{~K}$ in drinking waters from (OML) 30 , 58 , and 61 oil fields and host communities in Niger Delta regions of Nigeria. J Environ Radio 2013; 116: 197-200.

24. Environmental issues in the Niger Delta. en.m.wikipedia.org 2016.

25. Ihiala-Wikipedia en.m.wikipedia.org 2016.

26. Shirley A. Which are the world's most polluted cities? (World Economic Forum) https://www.weforum.org/agenda/2016/05/ which-are-the-world-s-most-polluted-cities/ 2016.

27. Ilemobayo O, Kolad IE. Profile of Heavy Metals from Automobile Workshops in Akure, Nigeria. J Environ Sci Tech 2008; 1: 19-26.

28. Chukwujindu MA, Iwegbue ES. Williams et al. Characteristic Levels of Total Petroleum Hydrocarbon in Soil Profiles of Automobile Mechanic Waste Dumps. Inter J Soil Sci 2008; 3: 48-51.

29. Agency for Toxic Substances and Disease Registry (ATSDR). Toxicological profile for total petroleum hydrocarbons (TPH). Atlanta, GA: U.S. Department of Health and Human Services, Public Health Service 1999.

30. World Health Organization: World Health Statistics, Life expectancy, Geneva 2016.

31. Egwurugwu JN, Nwafor A, Chinko BC, et al. Effects of prolonged exposure to gas flares on the lipid profile of humans in the Niger Delta region, Nigeria. Am J Res Com 2013; 1: 115-145.

32. Egwurugwu JN, Nwafor A, Olorunfemi OJ, et al. Impact of prolonged exposure to oil and gas flares on human renal functions. Int Res J Med Sci 2013; 1; 9-16.
33. Lee SC, Chiu MY, Ho KF, et al. Volatile organic compounds (VOCs) in urban atmosphere of Hong Kong. Chemosphere 2002; 48: 375-382.

34. Nabi G, Amin M, Khan AA. Reproductive health in rickshaw drivers: Occupational Exposure to Environmental Stressor: Bali Med 2014; 3: 78-84.Burns CJ, Boswell

35. JM, Olsen GW. Liver enzyme activity and body mass index. J Occup Environ Med 1996; 38: 1248-1252.

36. Dioka CE, Orisakwe OE, Adeniyi FAA et al. Liver and renal function tests inartisans occupationally exposed to lead in mechanic village in Nnewi, Nigeria. Int J Environ Res Pub Health 2004; 1: 21-25.

37. Pachathundikani SK, Vargese ET. Blood zinc protoporphhyrin, serum total protein and total cholesterol levels in automobile workshop workers in relation to lead toxicity. Ind J Clin Biochem 2006; 21: 114117.

38. Patil AJ, Bhagwat VR, Patil JA, et al. Occupational lead exposure in battery manufacturing workers, silver jewelry workers, and spray painters in western Maharashtra (India): effect on liver and kidney function. J Basic Clin Physiol Pharmacol 2007; 18: 87-100.

39. Ezejiofor TIN, Ezejiofor AN, Orisakwe OE, et al. Anicteric hepatoxicity: a potential health risk of occupational exposures in Nigerian petroleum oil refining and distribution industry. J Occupl Medd Toxicol 2014; 9: 3.

40. Dongre NN, Suryakar AN, Patil AJ et al. Occupational Lead Exposure in Automobile Workers in North Karnataka (India): Effect on Liver and Kidney Functions. Al Ameen J Med Sci 2010; 3: 284-292.

41. Ajani EO, Ajibola A, Salau BA, et al. Preliminary report on hepatic and cardiovascular risk assessment of automobile mechanics in Nigeria. Afr $\mathrm{J}$ Biotech 2011; 10: 1705-1711.

42. Abou-ElWafa HS, Albadry AA, El-Gilany $A$, et al. Some Biochemical and Hematological Parameters among Petrol Station Attendants: A Comparative Study. BioMed Research International 2015; 6 p.

43. Ita SO, Udofia UA. Comparative Study of Some Haematological Parameters in Rats Following Ingestion of Crude Oil (Nigerian 
Bonny Light), Petrol, Kerosene and Diesel. Asian J Biol Sci 2011; 4: 498-505.

44. Udonwa,NE Uko EK, Ikpeme BM, et al. Exposure of Petrol Station Attendants and Auto Mechanics to Premium Motor Sprit Fumes in Calabar, Nigeria. J Environ Pub Health 2009: 5p.

45. Kamal A, Malik RN. Hematological Evidence of Occupational Exposure to Chemicals and Other Factors among AutoRepair Workers in Rawalpindi, Pakistan. Osong Pub Health Res Perspect 2012; 3: 229-234.

46. Wiwanitkit V. Plateletcrit, mean platelet volume, platelet distribution width: its expected values and correlation with parallel red blood cell parameters. Clin Appl Thromb Hemost 2004; 10:175-178.

47. Giovanetti TV, Nascimento AJ, Paula J. Platelet indices: laboratory and clinical applications. Rev Bras Hematol Hemoter 2011; 33: 164-165.

48. Botma J, Mogongoa LF, Jaftha AD et al. Reference ranges for platelet indices using Sysmex XE-2100 blood analyser. Medical Technology SA 2012; 26: 17-22.

49. Akpinar I, Sayin MR, Gursoy YC, et al. Plateletcrit and red cell distribution width are independent predictors of the slow coronary flow phenomenon $\mathrm{J}$ Cardiology 2014; 63: 112-118.

50. Zhang S, Cui YL, Diao MY, et al. Use of platelet indices for determinating illness severity and predicting prognosis in critically ill patients. Chin Med J 2015; 128: 2012-2018.

51. Budak YU, Polat M, Huysal K. The use of platelet indices, plateletcrit, mean platelet volume and platelet distribution width in emergency non-traumatic abdominal surgery: a systematic review. Biochem Med (Zagreb) 2016; 26: 178-193.

52. Fairweather-Tait SJ, Bao Y, Broadley MR, et al. Selenium in Human Health and
Disease. Antioxidants \& Redox Signaling 2011; 14: 1338-1383.

53. Rayman MP. Selenium and human health. Lancet 2012; 379: 1256-1268.

54. Chattopadhyay O. Pulmonary function in automobile repair workers. Indian $\mathbf{J}$ Community Med 2007; 32: 40-42.

55. Hulke SM, Patil PM, Thakare AE, et al. Lung Function Test in Petrol Pump Workers. J Physiol Pharm Pharmacol 2012; 2: 71-75.

56. Hansen ES. Mortality of auto mechanics A ten-year follow-up. Scand J Work Environ Health 2017; 15: 43-46.

57. Gore AC, Crews D, Doan LL, et al. Introduction to endocrine disrupting chemicals (edcs) a guide for public interest organizations and policy-makers 2014; pp 1-69.

58. Schrader SM, Marlow KL. Assessing the reproductive health of men with occupational exposures. Asian J. Andrology 2014; 16: 23-30.

59. Fischer VA, Fischer CE, Akpaso M, et al. Hormonal assays following oral administration of bonny light crude oil on male wistar rats. Exper Clin Anat 2013; 12: 53-56.

60. Nwafor A, Asiegbu LN, Adienbo MO, et al. Anti-fertility activity of ingestion of Nigerian Bonny light crude oil contaminated feed in male reproduction: A possible hyothamo-pituitary axis mechanism. Am J Res Comm 2013; 1: 210218.

61. Ogechukwu OJ, Ajuluchukwu NA, Ifedioranma OS, et al. Histopathological and hormonal disrupting effects of escravos crude oil on the ovary of chinchilla rabbits. J Toxic Environ Health Sci 2014; 6: 31-37. 


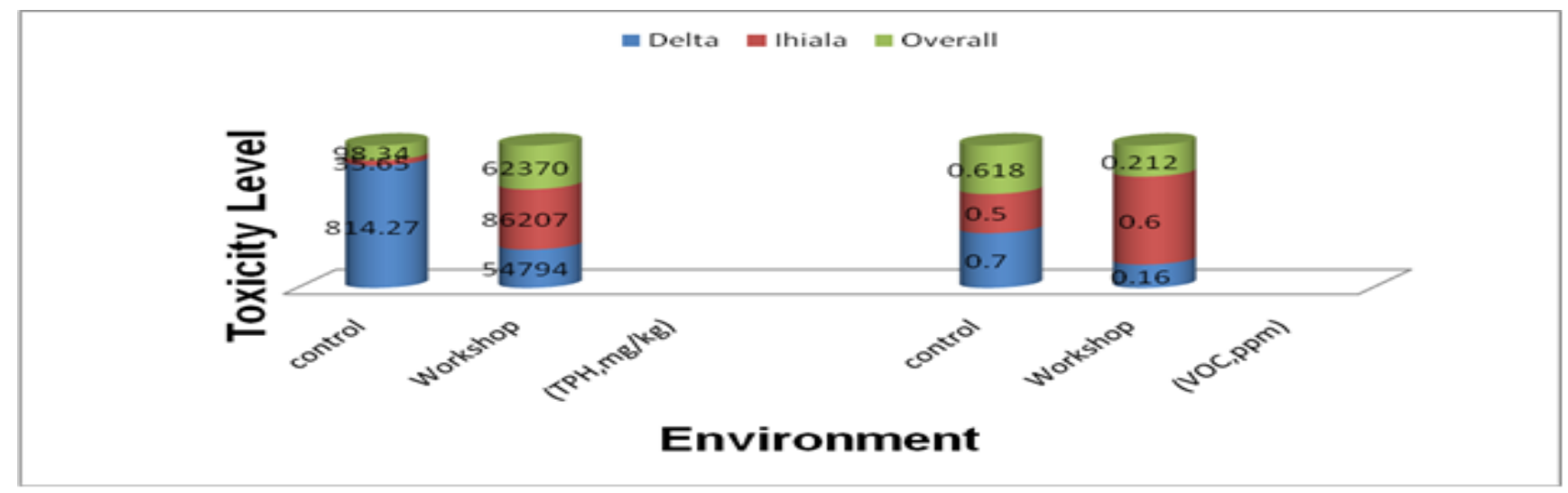

Figure 1: Harmonic mean toxicity values of volatile organic compounds and total petroleum hydrocarbons.

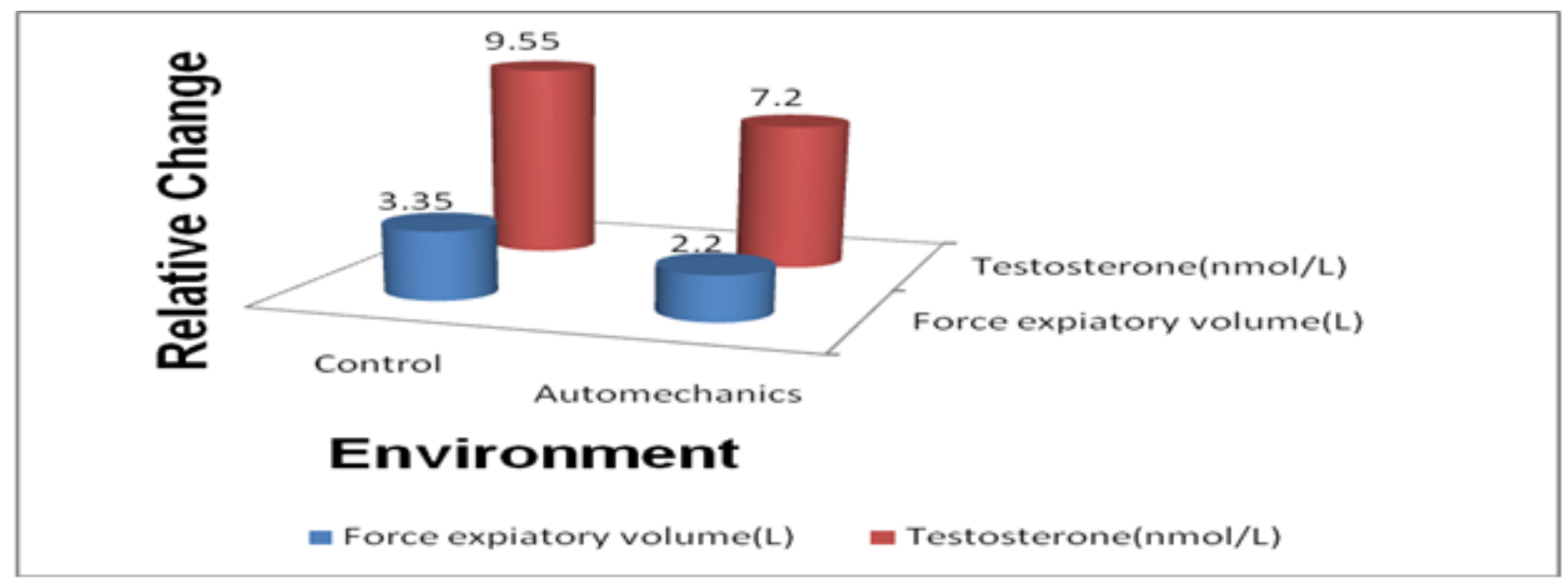

Figure 2: Mean force expiratory volume and testosterone level

Table 1: Mean values of biochemical markers of liver function

\begin{tabular}{|l|c|c|}
\hline \multicolumn{1}{|c|}{ Biochemical Parameters } & Control & Auto-mechanic \\
\hline Aspartate aminotransferase $(\mathrm{U} / \mathrm{L})$ & $0.36 \pm 0.49$ & $0.28 \pm 0.19^{*}$ \\
\hline Alanine transaminase $(\mathrm{U} / \mathrm{L})$ & $0.25 \pm 0.07$ & $0.16 \pm 0.14^{*}$ \\
\hline Alkaline phosphatase $(\mathrm{U} / \mathrm{L})$ & $3.06 \pm 0.50$ & $5.70 \pm 0.60^{*}$ \\
\hline Total Bilirubin $(\mathrm{mg} / \mathrm{dl})$ & $1.76 \pm 0.63$ & $2.67 \pm 0.24^{*}$ \\
\hline Conjugated bilirubin $(\mu \mathrm{mol} / \mathrm{dl})$ & $2.33 \pm 0.00$ & $0.90 \pm 0.90^{*}$ \\
\hline Albumin $(\mathrm{g} / \mathrm{l})$ & $8.29 \pm 1.48$ & $1.78 \pm 0.63^{*}$ \\
\hline Total Protein $(\mathrm{g} / \mathrm{l})$ & $3.20 \pm 0.43$ & $4.92 \pm 0.16^{*}$ \\
\hline
\end{tabular}

Values are presented as mean \pm SEM; $P \leq 0.05^{*}$ means test values are statistically significant in comparison to control 
Table 2: Mean values of red blood cell profile

\begin{tabular}{|l|c|c|}
\hline \multicolumn{1}{|c|}{ Blood parameters } & Control & Auto-mechanic \\
\hline Red blood cell count $\left(\times 10^{12} / \mathrm{L}\right)$ & $4.29 \pm 0.19$ & $3.09 \pm 0.54^{*}$ \\
\hline Haemoglobin $(\mathrm{g} / \mathrm{dl})$ & $11.35 \pm 2.85$ & $9.3 \pm 1.5^{*}$ \\
\hline Haematocrit $(\%)$ & $28.7 \pm 2.2$ & $26.05 \pm 3.15^{*}$ \\
\hline Mean corpuscular volume $(\mathrm{fl})$ & $72.05 \pm 12.85$ & $87.9 \pm 1.8^{*}$ \\
\hline Mean corpuscular haemoglobin $(\mathrm{pg})$ & $23.7 \pm 4.7$ & $28.15 \pm 2.45^{*}$ \\
\hline Mean corpuscular haemoglobin concentration $(\mathrm{g} / \mathrm{dl})$ & $33.0 \pm 1.0$ & $33.3 \pm 0.8$ \\
\hline
\end{tabular}

Values are presented as mean \pm SEM; $P \leq 0.05 *$ means test values are statistically significant in comparison to control

Table 3: Mean values of white blood cell profile

\begin{tabular}{|l|c|c|}
\hline \multicolumn{1}{|c|}{ Parameters } & Control & Auto-mechanic \\
\hline White blood cell count $\left(\times 10^{9} / \mathrm{L}\right)$ & $8.20 \pm 5.57$ & $7.42 \pm 0.50^{*}$ \\
\hline Neutrophil $\left(\times 10^{9} / \mathrm{L}\right)$ & $2.52 \pm 1.1$ & $0.84 \pm 0.84^{*}$ \\
\hline Lymphocyte $\left(\times 10^{9} / \mathrm{L}\right)$ & $4.50 \pm 1.80$ & $1.62 \pm 0.08^{*}$ \\
\hline Monocyte $\left(\times 10^{9} / \mathrm{L}\right)$ & $0.58 \pm 0.53$ & $0.08 \pm 0.08^{*}$ \\
\hline Eosinophil $\left(\times 10^{9} / \mathrm{L}\right)$ & $1.36 \pm 1.29$ & $0.27 \pm 0.27^{*}$ \\
\hline Basophils $\left(\times 10^{9} / \mathrm{L}\right)$ & $0.09 \pm 0.01$ & $0.02 \pm 0.02^{*}$ \\
\hline
\end{tabular}

Values are presented as mean \pm SEM; $P \leq 0.05 *$ means test values are statistically significant in comparison to control

Table 4: Mean value of platelet parameters

\begin{tabular}{|l|c|c|}
\hline \multicolumn{1}{|c|}{ Platelet Parameters } & Control & Auto-mechanic \\
\hline Platelet count (FL) & $267 \pm 101$ & $107 \pm 97^{*}$ \\
\hline Mean Platelet Volume (FL) & $8.85 \pm 0.75$ & $9.05 \pm 1.95^{*}$ \\
\hline Platelet Distribution Width (FL) & $15.25 \pm 0.05$ & $15.10 \pm 0.6^{*}$ \\
\hline Platetcrit (\%) & $0.23 \pm 0.06$ & $0.09 \pm 0.08^{*}$ \\
\hline
\end{tabular}

Values are presented as mean \pm SEM; $P \leq 0.05^{*}$ means test values are statistically significant in comparison to control

Table 5: Blood metals

\begin{tabular}{|l|c|c|}
\hline \multicolumn{1}{|c|}{ Metals (ppm) } & Control & Auto-mechanics \\
\hline Chromium & $0.00 \pm 0.00$ & $0.09 \pm 0.06$ \\
\hline Mercury & $0.00 \pm 0.00$ & $0.00 \pm 0.00$ \\
\hline Copper & $0.07 \pm 0.00$ & $0.07 \pm 0.01$ \\
\hline Zinc & $0.61 \pm 0.05$ & $0.61 \pm 0.05$ \\
\hline Cadmium & $0.01 \pm 0.00$ & $0.01 \pm 0.01$ \\
\hline Nickel & $0.00 \pm 0.00$ & $0.00 \pm 0.00$ \\
\hline Arsenic & $0.00 \pm 0.00$ & $0.00 \pm 0.00$ \\
\hline Vanadium & $0.05 \pm 0.00$ & $0.05 \pm 0.00$ \\
\hline Selenium & $0.31 \pm 0.28$ & $0.04 \pm 0.00^{*}$ \\
\hline
\end{tabular}


This manuscript was peer-reviewed

Mode of Review: Single-blinded

\section{Editor: Dr. Sabina Khanam}

International Journal of Pharmaceutics and Pharmacology is an open access, peer reviewed journal published by Edwiser International.

Submit your valuable manuscript at-

editor.ijpp@edwiserinternational.com

submit.manuscript@edwiserinternational.com

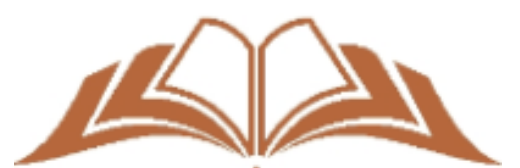

$\mathrm{E} D \mathrm{~W}(\hat{\theta} \mathrm{SER}$
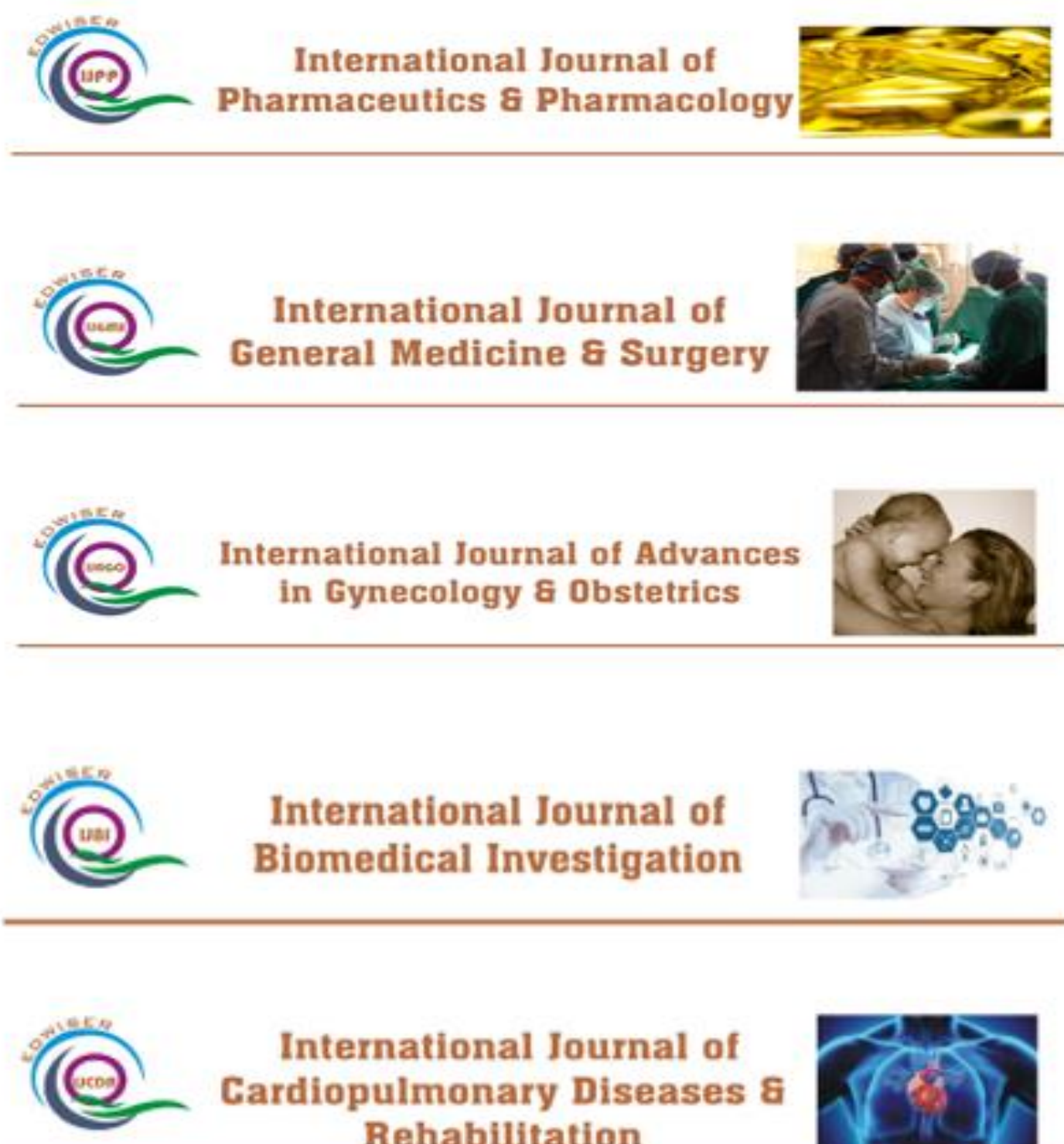

\section{International Journal of Cardiopulmonary Diseases \& Rehabilitation}

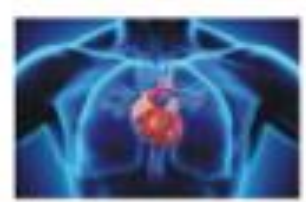

